\title{
A new method for determining surface concentrations of marine natural products on seaweeds
}

\author{
R. de Nys*, S. A. Dworjanyn, P. D. Steinberg \\ School of Biological Science and Centre for Marine Biofouling \& Bio-Innovation, University of New South Wales, \\ Sydney 2052, Australia
}

\begin{abstract}
To understand the role of marine natural products in surface mediated ecological interactions - such as biofouling - we need to be able to quantify metabolites at or near the relevant surfaces. We describe a new technique for determining the concentration of natural products on the surface of marine algae. Surface metabolites were quantified for 2 red algae, Delisea pulchra and Laurencia obtusa, by dipping the algae in hexane for 20 to $40 \mathrm{~s}$ at room temperature. This allowed for quantitative extraction of non-polar natural products from the surface of the thalli without disrupting cells (as determined by epifluorescence microscopy). More stringent extraction procedures using other solvents, or longer extraction times in hexane $(>50 \mathrm{~s})$, caused significant quantifiable cell damage Natural products in the surface extracts were then measured using gas chromatography-mass spectroscopy (gc-ms). Mean total surface concentration of natural products from $D$. pulchra were $250 \mathrm{ng}$ $\mathrm{cm}^{-2}$, but $<1 \mathrm{ng} \mathrm{cm} \mathrm{cm}^{-2}$ for $L$. obtusa. These results contrast to whole plant levels of total secondary metabolites in the 2 algae, which worc significantly higher in L. obtusa ( $7 \mu \mathrm{g} \mathrm{mg}^{-2}$ dry weight) than in D. pulchra (3.4 $\mathrm{kg} \mathrm{mg}^{-2} \mathrm{dry}$ weight). Dipping thalli in hexane for $30 \mathrm{~s}$ also caused no cell lysis in 8 other species of macroalgae. This suggests that the procedure is more broadly applicable for the quantification of non-polar surface metabolites on seaweeds, and other organisms with resistant surface cells. Our results highlight the need to determine where compounds occur, and at what concentration, if we are to understand their ecological roles.
\end{abstract}

KEY WORDS: Surface mediated interactions - Biofouling $\cdot$ Marine natural products $\cdot$ Delisea pulchra Marine algae - Furanones Chemical ecology

\section{INTRODUCTION}

Natural products, also known as secondary metabolites, mediate a wide range of ecological interactions between marine organisms (Hay 1996). Many of these interactions, including fouling (Davis et al. 1989, Wahl 1989, Clare 1996), competition for space (de Nys et al. 1991), and recognition of food (Tamburri \& ZimmerFaust 1996), occur at the surfaces of the relevant organisms. Of these various interactions, fouling, or 'the process of adsorption, colonisation and development of living and non-living material on an immersed substratum' (Clare 1996), has perhaps received the most attention in the literature. Both micro- (bacteria

\footnotetext{
•E-mail:r.denys@unsw.edu.au
}

and diatoms) and macro- (algae and invertebrates) fouling can have a wide range of deleterious effects on host organisms (Sand-Jensen 1977, Dixon et al. 1981, D'Antonio 1985, Williams \& Seed 1992, Littler \& Littler 1995, Wahl \& Hay 1995, Kushmaro et al. 1996).

That sessile marine organisms (sponges, ascidians, seaweeds, etc.) inhibit fouling of their surfaces via the production of chemical inhibitors has been a theme in the literature for many years (e.g. Sieburth \& Conover 1965, Davis et al. 1989, Clare 1996 and references therein). And indeed, crude chemical extracts of marine organisms, or specific metabolites, which deter or kill fouling organisms in laboratory assays have been isolated from a broad range of marine bacteria, algae, seagrasses, and invertebrates (reviewed by Holmström \& Kjelleberg 1994, Clare 1996). However, as previous authors have highlighted (Davis et al. 
1989, Hay 1996), one major difficulty with interpreting the vast majority of these studies is that rarely is any infomation provided on the concentration of metabolites at or near the surface of the host organisms. Although an extract or metabolite may be active at low concentrations, unless it can be demonstrated that those concentrations are present in situ at or near the surface of the host, an antifouling function cannot be inferred. Only a handful of studies have addressed this issue by attempting to measure ecologically relevant concentrations of metabolites, and then testing those concentrations against ecologically relevant fouling organisms. For example, Schmitt et al. (1995) found that the lipid soluble extract of surface swabs of the brown alga Dictyota menstrualis, which contained the diterpenes pachydictyol $\mathrm{A}$ and dictyol $\mathrm{E}$, inhibited the settlement of larvae of the common epibiont Bugula neretina. Jennings \& Steinberg (1997) showed that realistic concentrations of mixed phlorotannin fractions from Ecklonia radiata had no effect on settlement and germination of propagules of the green alga Ulva lactuca, an epiphyte of these kelps. However, even in these studies there was no quantitative measurement of individual, characterized secondary metabolites at or near the surface of the host.

In order to further advance our understanding of how marine natural products mediate interactions at surfaces we need methods for quantifying these compounds at or near the relevant surfaces. Such methods would be applicable not only to inhibition of fouling, but also to allelopathy (de Nys et al. 1991), induction of larval settlement (Pawlik 1992), recognition of food (Tamburri \& Zimmer-Faust 1996), and many others.

Here we describe such a methodology for the extraction and quantification of non-polar secondary metabolites from the surfaces of marine algae. The method is based on similar studies from terrestrial chemical ecology, where quantitative analysis of furanocoumarins (Zobel \& Brown 1988, 1990a, b), flavanoids (Stevens et al. 1995), flavonid aglycones (Wollenweber et al. 1987), and other metabolites (Tulloch 1987, Eigenbrode et al. 1991) has highlighted the importance of secondary metabolites on surfaces for ecological interactions (Chapman \& Bernays 1989). We combined chemical and microscopic studies in order to optimise extraction and quantification of surface metabolites while minimising damage to cells. We first focused on 2 chemically rich red algae. Delisea pulchra and Laurencia obtusa, and then applied the technique in a non-quantitative way to an additional 8 species of algae in order to determine whether the technique was more broadly applicable to seaweeds. The ecological roles of secondary metabolites in $D$. pulchra and $L$. obtusa are discussed in regard to our results.

\section{MATERIALS AND METHODS}

Study organisms. The red algae Delisea pulchra (Greville) Montagne and Laurencia obtusa Lamouroux are common subtidal species in the Sydney, NSW, Australia, region. $D$. pulchra is abundant year round; L. obtusa is common during the warmer months (December to May). Both species contain biologically active non-polar secondary metabolites. D. pulchra produces a range of halogenated furanones and enones (Fig. 1, 1 to 4) (Kazlaukas et al. 1977, de Nys et al. 1992, 1993). L. obtusa from this location contains a range of halogenated sesquiterpenes and diterpenes with palisadin A (5), aplysistatin (6), brasilenol (7), and palisadin B (8) (Fig. 1) the most abundant (Battista 1995).

Other marine algae used in this study included 5 species of brown algae, Dictyopteris acrostichoides (J. Agardh) Boergesen, Dictyota dichotoma (Hudson) Lamouroux, Zonaria diesingiana J. Agardh, and Dilophus marginatus J. Agardh, Sargassum linearifolium (Turner) C. Agardh; 2 species of red algae, Laurencia rigida Agardh and Pterocladia capillacea (S.G. Gmelin) Bornet; and 1 green alga, Ulva sp. All species were collected from the sublittoral zone at Nielsen

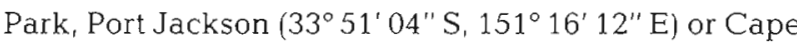

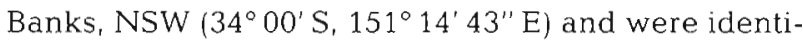
fied using appropriate taxonomic keys (Womersley 1984, 1987, 1996, Farrant \& King 1989).

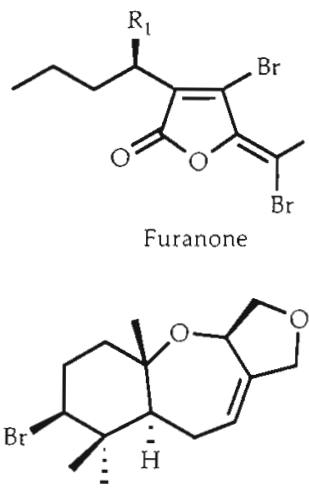

(5) Palisadin A

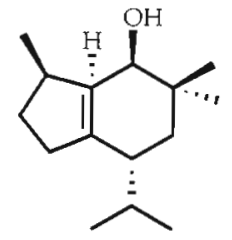

(7) Brasilenol
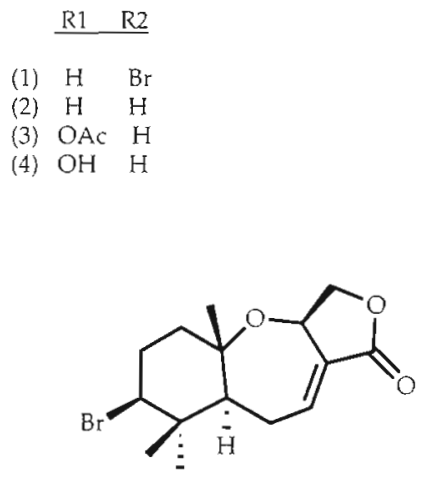

(6) Aplysistatin

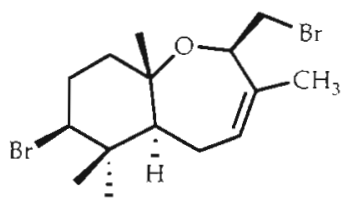

(8) Palisadin B
Fig. 1. Structure of the major secondary metabolites of Delisea pulchra ( 1 to 4) and Laurencia obtusa (5 to 8) 
Whole plant chemistry of Delisea pulchra and Laurencia obtusa. In order to confirm the presence of secondary metabolites in the algae used here, and to compare levels of surface chemistry with those of whole plants, the concentration of secondary metabolites was measured for whole plants of $D$. pulchra (see also de Nys et al. 1996) and L. obtusa. Ten plants of each species were collected at the same time and locations as plants used for surface extraction. Plants were weighed, frozen, freeze dried and reweighed prior to the extraction. The freeze dried algae were homogenised and $200 \mathrm{mg}$ of tissue extracted in dichloromethane (as per de Nys et al. 1996). The extract was taken to dryness and the resultant extract prepared for analysis by gc-ms (de Nys et al. 1996. and below).

Gas chromatography-mass spectrometry (gc-ms). Extracts for gc-ms were dissolved in ethyl acetate (EtOAc) containing napthalene as an internal standard at a concentration of $10 \mu \mathrm{g} \mathrm{ml}^{-1}$. Surface extracts for gcms were made up in $400 \mu \mathrm{l}$ of EtOAc (+internal standard). Whole plant extracts were made up in $5 \mathrm{ml}$ of EtOAc (+internal standard). Standards used in gc-ms for both Delisea pulchra and Laurencia obtusa were isolated from dichloromethane extracts of the algae by established protocols (de Nys et al. 1993, Battista 1995). All standards were identified by comparison of ${ }^{1} \mathrm{H}$ and ${ }^{13} \mathrm{C}$ NMR (nuclear magnetic resonance) data with published data. Gas chromatography was performed using a Hewlett Packard (HP) 5980 series II gas chromatograph (GC) and a polyimide-coated fusedsilica capillary column (BPX5, $12 \mathrm{~m}$ length, $0.15 \mathrm{~mm}$ i.d., $0.22 \mu \mathrm{m}$ modified siloxane stationary phase; SGE Pty Ltd). All injections were performed in the splitless mode with an inlet pressure of $100 \mathrm{kPa}$. The injection port was held at $280^{\circ} \mathrm{C}$ and the interface at $300^{\circ} \mathrm{C}$. For D. pulchra the $\mathrm{GC}$ was held at $50^{\circ} \mathrm{C}$ for $1.5 \mathrm{~min}$ and ramped at $20^{\circ} \mathrm{C} \mathrm{min} \mathrm{m}^{-1}$ to $300^{\circ} \mathrm{C}$ (and held there for 10 min). For L. obtusa metabolites the GC was held at $50^{\circ} \mathrm{C}$ for $1.5 \mathrm{~min}$ and ramped at $20^{\circ} \mathrm{C} \mathrm{min}$ m $^{-1}$ to $310^{\circ} \mathrm{C}$ (and held there for $10 \mathrm{~min}$ ). Helium was used as the carrier gas.

The mass spectrometry was performed on a HP 5971 Mass Selective Detector (MSD). Ions characteristic of the internal standard, 4 metabolites for $D$. pulchra (compounds 1 to 4 ) and 4 metabolites for L. obtusa (5 to 8) were monitored in the selected ion monitoring (SIM) mode and were quantitatively analysed using purified standards. Quantification was performed by measuring peak areas for each compound and the internal standard. The ratio of peak areas (cmpd/internal standard) was calculated for each metabolite (cmpds 1 to 8 ) and converted to concentration by reference to standard curves. To determine the surface concentration of secondary metabolites the surface areas of pieces of $D$. pulchra and $L$. obtusa were calculated using a wet weight $(\mathrm{mg})$ to surface area $\left(\mathrm{cm}^{2}\right)$ conversion factor. To calculate the conversion factor fresh pieces of $D$. pulchra and $L$. obtusa between 5 and $500 \mathrm{mg}$ wet weight were dried and weighed before being placed on white paper. The algae were then immediately scanned and analysed for surface area using the NIH Imaging Program. For the planar D. pulchra, surface area was calculated to account for the area on both sides of the alga. For the cylindrical $L$. obtusa, the length and cross section of the alga were measured and the surface area of the cylinder calculated. The regression between wet weight and surface area for both species had associated $R^{2}$ values greater than 0.97 and probabilities less than 0.001 .

Extraction procedure for surface metabolites. In an initial test to determine the appropriate solvent for extraction of algal surfaces, 5 organic solvents were assessed for their effects on the lysis of epithelial cells of Delisea pulchra and Laurencia obtusa using epifluorescence microscopy. The solvents, in order of increasing polarity, were hexane (least polar), dichloromethane, diethyl ether, ethyl acetate and methanol (most polar). All solvents were of analytical reagent grade. Twenty $\mathrm{ml}$ of each solvent was added to a $100 \mathrm{ml}$ beaker and a $-1.5 \mathrm{~g}$ piece of either $D$. pulchra or $L$. obtusa, which had been dried in a salad spinner, was held in each of the solvents for times of $10,20,30$ and $60 \mathrm{~s}$ and vortexed.

After each time period the piece was directly observed and qualitatively assessed for the presence of lysed cells using epifluorescence microscopy. The surface cells of whole axes were observed for fluorescence on a Leitz epifluorescent microscope with filter block D (BP 355-425, dichromic mirror 455, LP 460 $\mathrm{nm})$. Pigments in chloroplasts of algae autofluoresce when excited under near UV to blue light, emitting a yellow to red fluorescence (O'Brien \& McCully 1981). Healthy living cells have discrete chloroplasts which are identified by their fluorescence. When the plasmalemma of a cell is disrupted the chloroplasts of the cell lyse, filling the whole cell with pigment. This change is observed using epifluorescence microscopy. Using this technique surface cells of axes were qualitatively and quantitatively assessed for cell lysis.

The effects of extraction in hexane (our eventual solvent of choice) on cell lysis were measured quantitatively by counting the number of lysed versus intact cells for individual pieces of Delisea pulchra $(\mathrm{n}=12)$ and Laurencia obtusa $(\mathrm{n}=6)$ subjected to extraction in hexane $(20 \mathrm{ml})$ as described above for $10,20,30,40,50$ and $60 \mathrm{~s}$. The effect of extraction time was directly assessed following extraction by counting the number of lysed cells per unit field $\left(0.1 \mathrm{~mm}^{2}\right)$ for tissue from each extraction time. 
Except for small plants, it is difficult to dip whole thalli. Therefore, an additional validation step for the procedure was performed to ensure that there was no effect of cutting the plants which were to be dipped. To assess the effects of cutting on surface extraction, samples ( 1 to $1.5 \mathrm{~g}$ wet weight) of Delisea pulchra were generated by a single cut to the thallus, and then extracted in 2 ways. In the first, the pieces of plant were held such that the cut end did not contact the hexane when vortexed for $30 \mathrm{~s}$. In the second, the pieces of plant were immersed, including the cut end, and vortexed in hexane for $30 \mathrm{~s}$. After vortexing, the algae were removed and the samples taken to dryness in air and the resultant extract prepared for analysis by gc-ms.

Quantitative analysis of secondary metabolite chemistry of Delisea puIchra and Laurencia obtusa following surface extraction. Levels of secondary metabolites for both $D$. pulchra and $L$. obtusa were measured following extraction by hexane. Ten plants collected from the field were dried in a salad spinner and single pieces ( 1.2 to $1.6 \mathrm{~g}$ wet weight) were cut from a plant for extraction at each time. Pieces were extracted for $10,20,30,40,50$ or $60 \mathrm{~s}$. Upon cutting each piece was immediately placed into hexane and vortexed for the required period. After vortexing the alga was removed and the hexane taken to dryness at room temperature and the resultant extract prepared for analysis by gcms.

Effects of solvent extraction on the epithelial cells of other algal species. To assess the broader application of the technique to other algal species the effect of surface extraction on cell lysis was examined for 5 species of brown algae, Dictyopteris acrostichoides, Dictyota dichotoma, Zonaria diesingiana, and Dilophus marginatus, Sargassum linearifolium, 2 other species of red algae, Laurencia rigida and Pterocladia capillacea; and 1 green alga, Ulva sp. Whole plants were collected from the field and after drying by spinning, samples were taken from the top portions of the thallus for surface extraction in hexane at 30 and $60 \mathrm{~s}$, and in methanol at $30 \mathrm{~s}$. Samples were extracted and immediately analysed for cell lysis using epifluorescence microscopy.

Statistical analyses. Metabolite levels and cell lysis were analysed using analysis of variance followed by Tukey's multiple range test (where appropriate). Homogeneity of variances was tested with Cochran's test. Concentrations of metabolites were analysed following arcsin $\sqrt{ }$ p transformation (Sokal \& Rohlf 1985). Analyses where more than 1 sample was taken from an individual plant were performed using plant as a blocked factor in ANOVA to partition the overall effect of variation among plants from the variation among individual parts of a plant (e.g. de Nys et al. 1996).

\section{RESULTS}

\section{Whole plant chemistry of Delisea pulchra and Laurencia obtusa}

Both Delisea pulchra and Laurencia obtusa are rich in non-polar secondary metabolites, and plants used in this study were no exception. Mean levels of secondary metabolites for $D$. pulchra were, in order of decreasing concentration, compound $3\left(1.56 \mathrm{ug} \mathrm{mg}^{-1}\right.$ dry weight), compound $4\left(0.77 \mu \mathrm{g} \mathrm{mg}^{-1}\right.$ dry weight), compound 1 $\left(0.55 \mu \mathrm{g} \mathrm{mg}^{-1}\right.$ dry weight) and compound $2(0.53 \mu \mathrm{g}$ $\mathrm{mg}^{-1}$ dry weight). Total concentration of furanones in D. pulchra averaged $3.41 \mu \mathrm{g} \mathrm{mg}^{-1}$ dry weight. Levels of metabolites in whole thalli of $L$. obtusa were, in order of decreasing concentration, palisadin $\mathrm{A}\left(3.70 \mu \mathrm{g} \mathrm{mg}^{-1}\right.$

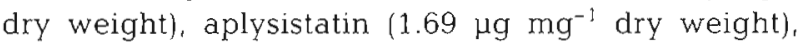
palisadin B (1.19 $\mathrm{g} \mathrm{mg}^{-1}$ dry weight) and brasilenol $\left(0.43 \mu \mathrm{g} \mathrm{mg}^{-1}\right.$ dry weight), with a total metabolite concentration of $7.01 \mathrm{\mu g} \mathrm{mg}^{-1}$ dry weight.

\section{Effects of solvents and extraction time on cell viability}

Of the 5 solvents tested for extraction of surface metabolites, all except hexane caused lysis of surface cells for both Delisea pulchra and Laurencia obtusa at all of the times tested (Table 1). Cells of $D$. pulchra dipped in hexane for 10,20 and $30 \mathrm{~s}$ remained intact (Fig. 2a, b), but exposure for $60 \mathrm{~s}$ caused lysis of cells (Fig. 2c). L. obtusa was more robust with most cells remaining intact after dipping in hexane for $60 \mathrm{~s}$. Lysis of cells (as percent of cells lysed) was then measured quantitatively at $10 \mathrm{~s}$ intervals following surface extraction in hexane. As suggested by Table 1, there was a significant effect of time of immersion in hexane on lysis of cells for D. pulchra (1-factor ANOVA, $p=0.0001 ;$ Fig. 3). No significant cell lysis occurred from 10 to $40 \mathrm{~s}$ (Fig. 2a, b), but it increased significantly from a mean of $1.55 \%$ at 40 s to greater than $20 \%$ when

Table 1 Effect of the time epithelial cells of Delisea pulchra (D.p.) and Laurencia obtusa (L.o.) were immersed in the solvents methanol, ethyl acetate, diethyl ether, dichloromethane and hexane as assessed by epifluorescence microscopy. $(-)$ Lysed cells present; $(+)$ cells intact

\begin{tabular}{lccccccccc}
\hline \multirow{2}{*}{ Solvent } & \multicolumn{8}{c}{ Time (s) } \\
& \multicolumn{1}{c}{10} & \multicolumn{2}{c}{20} & 30 & 60 \\
& D.p. L.o. & D.p. L.o. & D.p. L.o. & D.p. L.o. \\
\hline Methanol & - & - & - & - & - & - & - & - \\
Ethyl acetate & - & - & - & - & - & - & - & - \\
Diethyl ether & - & - & - & - & - & - & - & - \\
Dichloromethane & - & - & - & - & - & - & - & - \\
Hexane & + & + & + & + & + & + & - & + \\
& & & & & & & & \\
\hline
\end{tabular}




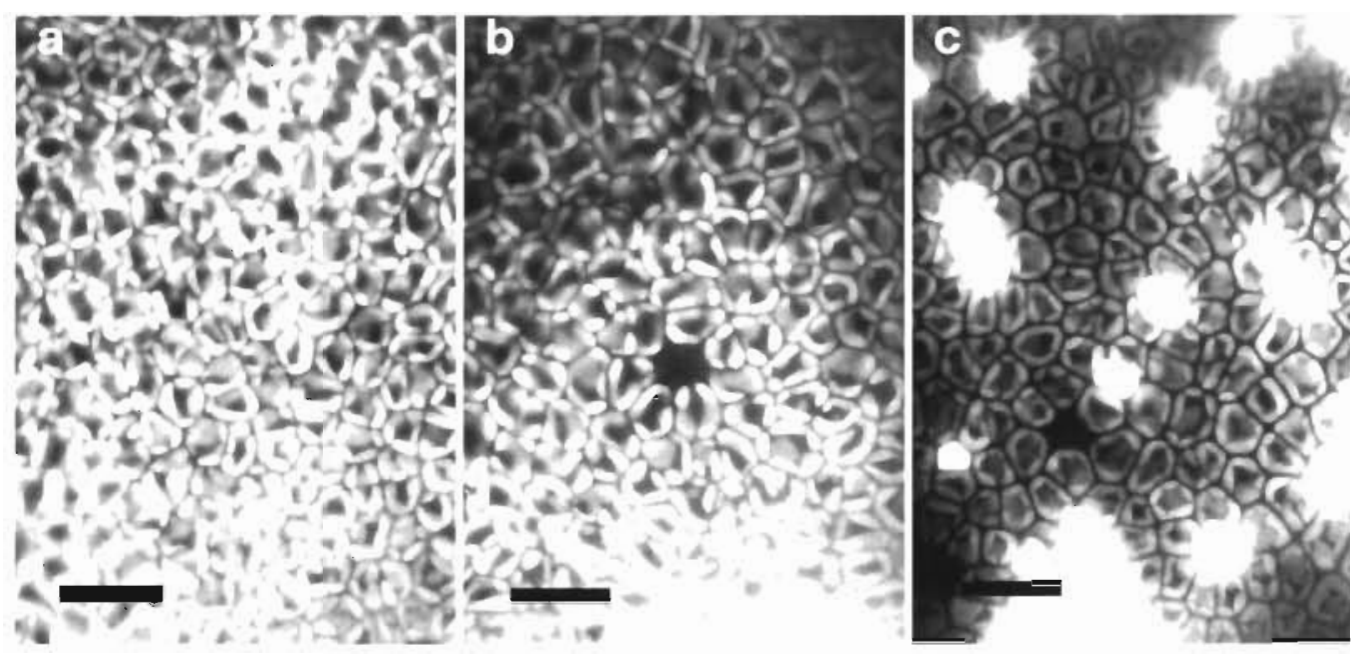

Fig. 2. Delisea pulchra. Fluorescence photomicrograph of the unstained surface which has been (a) untreated (b) extracted in hexane for $30 \mathrm{~s}$ and (c) extracted in hexane for $60 \mathrm{~s}$. Scale bars $=10 \mu \mathrm{m}$

tissue was immersed for 50 or $60 \mathrm{~s}$. Different immersion times had no significant effect on lysis of cells of $L$. obtusa at all immersion times ( 1 -factor ANOVA, $\mathrm{p}=0.508$; Fig. 3), although the increase in percent lysed after $60 \mathrm{~s}$ suggests that cells of more susceptible thalli were beginning to lyse. No cells were lysed in plants prior to immersion in hexane, suggesting the process of collection from the field had a minimal effect on the algae.

\section{Effect of cutting on surface chemistry}

There was no significant difference in the levels of total metabolites measured between Delisea pulchra which were extracted with the cut surface immersed versus not immersed (1-factor ANOVA, $F_{1,8}=0.001$, $p=0.982$ ). Concentrations of individual metabolites on the surface also did not vary between cut surface immersed and not immersed (2-factor ANOVA, analysis not shown).

\section{Quantitative analysis of surface secondary metabolites}

\section{Delisea pulchra}

Secondary metabolites were present on the surface of Delisea pulchra at concentrations greater than

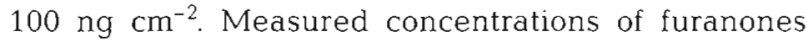
rapidly reached a plateau as a function of extraction time; concentrations of total metabolites extracted after 20, 30, or $40 \mathrm{~s}$ did not differ (Table 2; Tukey's test, $\alpha=$ 0.05; Fig. 4). There was a significant rise in measured levels of furanones for extraction times of more than $40 \mathrm{~s}$ (Table 2, Fig. 4), from approximately $250 \mathrm{ng} \mathrm{cm}^{-2}$

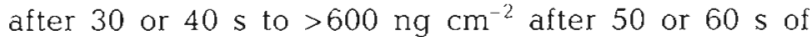
extraction. This corresponds to a significant rise in lysed cells between 40 and 50 s of extraction (Fig. 3). Changes in concentrations of individual metabolites were similar to each other, and to that of the total levels (note non-significant Metabolites $\times$ Time interaction term in Table 2). For each metabolite, there was no significant difference in metabolite concentrations for extraction times up to $40 \mathrm{~s}$ (Tukey's $\alpha=0.05$; Fig. 4). Metabolites 3 and 4 were present in the highest concentrations (122.4 and $113.3 \mathrm{ng} \mathrm{cm}^{-2}$ respectively) after extracting for $40 \mathrm{~s}$. Levels of all metabolites increased with longer extraction times, again corresponding to the increase in the number of cells lysed.

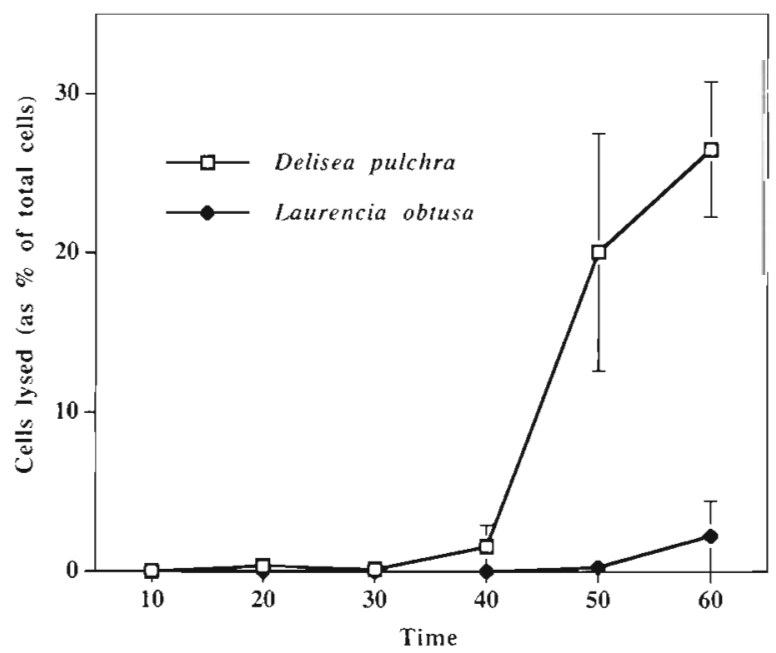

Fig. 3. Delisea pulchra and Laurencia obtusa. Percentage of cells lysed following extraction (immersion) in hexane at $10 \mathrm{~s}$ intervals from 0 to $60 \mathrm{~s}$. Means $\pm \mathrm{SE}, \mathrm{n}=12$ for $D$. pulchra, $\mathrm{n}=6$ for $L$. obtusa at each time 
Table 2. $(a, c)$ Two-factor analysis of variance for arcsin $\downarrow p$ transformed total concentration of metabolites extracted from the surface of (a) Delisea pulchra and (c) Laurencia obtusa plants at $10 \mathrm{~s}$ intervals from 10 to $60 \mathrm{~s}$. (b, d) Three-factor analysis of variance for arcsin $\vee p$ transformed concentration of metabolites extracted from the surface of (b) $D$. pulchra and (d) L. obtusa at $10 \mathrm{~s}$ intervals from 10 to $60 \mathrm{~s}$

\begin{tabular}{|c|c|c|c|c|}
\hline Factor & df & MS & $F$-test & p-value \\
\hline \multicolumn{5}{|c|}{ (a) Delisea pulchra 2-factor ANOVA } \\
\hline Block (= Plant) & 8 & 0.212 & 6.427 & 0.0001 \\
\hline Time & 5 & 0.233 & 7.074 & 0.0001 \\
\hline Error & 40 & 0.033 & & \\
\hline \multicolumn{5}{|c|}{ (b) Delisea pulchra 3-factor ANOVA } \\
\hline Block (= Plant) & 8 & 0.150 & 10.735 & 0.0001 \\
\hline Metabolites & 3 & 0.942 & 67.306 & 0.0001 \\
\hline Time & 5 & 0.163 & 11.633 & 0.0001 \\
\hline Metabolites $\times$ Time & 15 & 0.021 & 1.512 & 0.105 \\
\hline Error & 1.84 & 0.014 & & \\
\hline \multicolumn{5}{|c|}{ (c) Laurencia obtusa 2-factor ANOVA } \\
\hline Block (= Plant) & 9 & 0.002 & 1.520 & 0.170 \\
\hline Time & 5 & 0.012 & 11.702 & 0.0001 \\
\hline Error & 45 & 0.001 & & \\
\hline \multicolumn{5}{|c|}{ (d) Laurencia obtusa 3-factor ANOVA } \\
\hline Block (= Plant) & 9 & 0.002 & 3.060 & 0.003 \\
\hline Metabolites & 1 & 0.002 & 3.146 & 0.079 \\
\hline Time & 5 & 0.002 & 21.525 & 0.0001 \\
\hline Metabolites $\times$ Time & 5 & 0.001 & 1.114 & 0.358 \\
\hline Error & 99 & 0.001 & & \\
\hline
\end{tabular}

\section{Laurencia obtusa}

Surface concentrations of metabolites on Laurencia

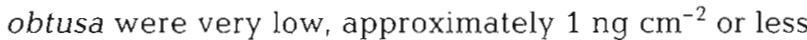
for extraction times of less than $40 \mathrm{~s}$. The level of total metabolites increased significantly with time (Table 2c, Fig. 5). The concentration of total metabolites for all

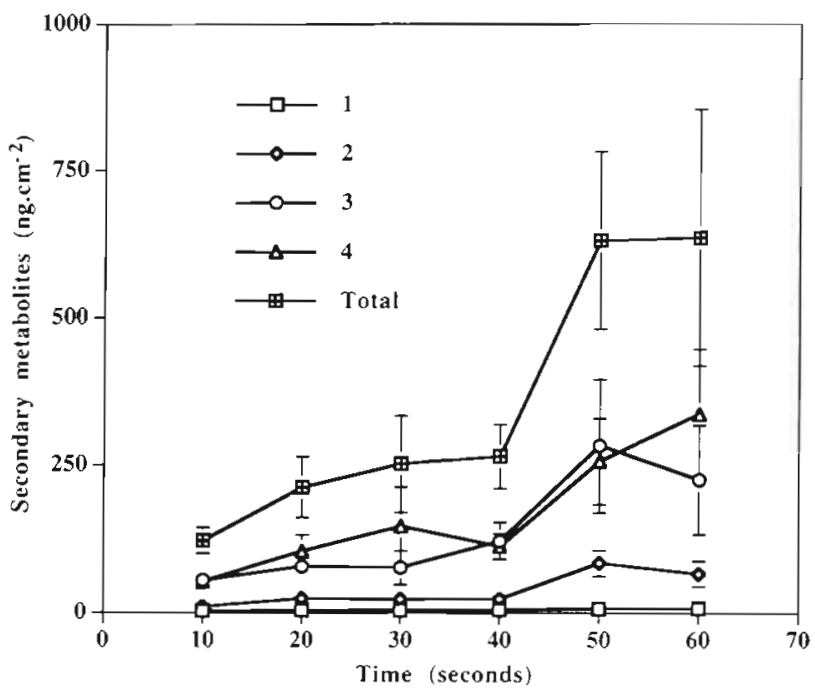

Fig. 4. Delisea pulchra. Concentration of furanones 1 to 4 and total metabolites extracted in hexane at $10 \mathrm{~s}$ intervals from 0 to $60 \mathrm{~s}$. Data are mean concentrations $\pm \mathrm{SE}, \mathrm{n}=10$ times up to $50 \mathrm{~s}$ was not significantly different (Tukey's test, $\alpha=0.05$; Fig. 5). There was a significant increase in the concentration of total metabolites between extraction times of 50 and $60 \mathrm{~s}$. This corresponds to an increase in the mean number of cells lysed at $60 \mathrm{~s}$ (Fig. 3). Only 2 of the 4 major metabolites measured in the whole plant, palisadin A and aplysistatin, were detected from the surface of $L$. obtusa. The concentration of both metabolites increased significantly with time (Table 2d, Fig. 5). Mean levels of metabolites were significantly higher after $60 \mathrm{~s}$ extraction time than after all other times (Tukey's test, $\alpha=0.05$; Fig. 5). For extraction times up to $40 \mathrm{~s}$, where no measurable cell lysis occurred, concentrations of metabolites on the surface of $L$. obtusa were typically 2 orders of magnitude less than those on Delisea pulchra.

\section{Effects of solvent extraction on the epithelial cells of other algal species}

The results of solvent extraction of a further 8 species of algae were similar to those in initial experiments of solvent and extraction time on cell lysis. Extraction in methanol caused widespread lysis of cells for all 8 algal species tested (Table 3 ). Cells of all species remained intact after extraction in hexane for $30 \mathrm{~s}$ (Table 3 ). Extraction in hexane for $60 \mathrm{~s}$ had no significant effect on cell lysis for all species except Laurencia rigida, where some lysis (comparable to that of L. obtusa) was observed. These results confirm that this technique is able to be applied to a broader range of marine algae including brown and green algal species.

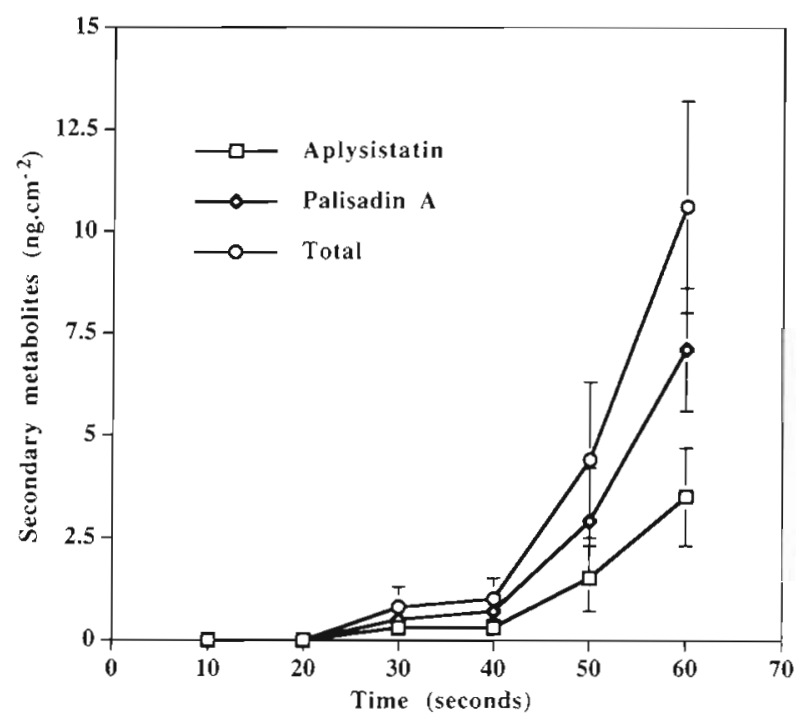

Fig. 5. Concentration of aplysistatin, palisadin A and total metabolites in Laurencia obtusa extracted in hexane at $10 \mathrm{~s}$ intervals from 0 to $60 \mathrm{~s}$. Data are mean concentrations $\pm \mathrm{SE}$, $n=10$ 
Table 3. Effect of immersion in methanol and hexane on epithelial cells of 8 algal species as assessed by epifluorescence microscopy. $\{-\}$ Lysed cells present $t_{i}(+)$ cells intact

\begin{tabular}{|lccc|}
\cline { 2 - 4 } \multicolumn{1}{c}{$\begin{array}{c}\text { Solvent } \\
\text { Time (s): }\end{array}$} & MeOH & \multicolumn{2}{c|}{ Hexane } \\
& 30 & 30 & 60 \\
\hline Dictyopteris acrostichoides & - & + & + \\
Dictyota dichotoma & - & + & + \\
Zonaria diesingiana & - & + & + \\
Dilophus marginatus & - & + & + \\
Sargassum linearifolium & - & + & + \\
Laurencia ngida & - & + & - \\
Pterocladia capillacea & - & + & + \\
Ulva sp. & - & + & + \\
\hline
\end{tabular}

\section{DISCUSSION}

Understanding the quantitative distribution of natural products within and on terrestrial plants - and consequently the way in which they are presented to other organisms - has proven fundamental to understanding their ecological role (Zobel \& Brown 1988, 1990a, b, Chapman \& Bernays 1989). Such information is also clearly central to determining the ecological role of natural products for marine organisms (Hay 1996). For surface mediated ecological interactions among marine organisms, new techniques need to be developed to extract and quantify secondary metabolites associated with the surface of the producing organism. The method described here enables non-polar natural products from the surface of seaweeds to be extracted and quantified with minimal apparent cell damage, and minimising extraction of intracellular secondary metabolites. Although only metabolites from Delisea pulchra and Laurencia obtusa were quantified in this study, the method should be applicable for quantifying non-polar secondary metabolites on the surfaces of marine algae in general, since the extraction procedure did not cause obvious lysis to cells of 8 other species of red, green, or brown algae. While other common chemically rich organisms - sponges, ascidians, etc. - were not examined here, the technique may be useful for any other marine organisms with sufficiently robust cell surfaces (which can be determined via microscopy). However, the technique is limited to nonpolar metabolites, and importantly the specific extraction solvent and immersion time need to be determined in each case to demonstrate a plateau in levels of secondary metabolites prior to cell lysis.

This hexane dip method has some advantages over swabbing the surface of an alga (Schmitt et al. 1995 , Dworjanyn unpubl.), which is the only other published method used to assess surface concentrations or activities of natural products from algae. It is difficult to swab uniformly over the surface of an alga, and for foliose algae such as Delisea pulchra or Laurencia obtusa it is also difficult to ascertain exactly how much surface area has been swabbed. As well as using the dip procedure to quantify actual metabolites, it can also be used (like swabbing) as a means of harvesting realistic concentrations of extract from a surface for subsequent biological testing (e.g. Tamburri \& Zimmer-Faust 1996). Here also it has some advantages over swabbing, as even supposedly 'clean' cotton swabs can contain contaminants which when extracted in organic solvents interfere with biological testing of target natural metabolites (de Nys pers. obs.).

The 2 algae studied in detail here provide a clear example of how whole plant chemistry can be misleading with regard to surface chemistry. Both Delisea pulchra (de Nys et al. 1993) and Laurencia obtusa (Erickson 1983, Battista 1995) are well studied, chemically rich algae. Whole plant levels of metabolites $(7.01 \mu \mathrm{g}$ $\mathrm{mg}^{-2}$ for L. obtusa and $3.41 \mu \mathrm{g} \mathrm{mg}^{-2}$ for $D$. pulchra) and levels of the most abundant metabolites (palisadin $A$ is present at $3.7 \mu \mathrm{g} \mathrm{mg}^{-2}$ in L. obtusa, furanone 3 at $1.56 \mu \mathrm{g} \mathrm{mg}^{-2}$ in $D$. pulchra) in the 2 species are roughly similar. However, surface concentrations of metabolites of the species differed by more than 2 orders of magnitude, with metabolites barely present (e.g. $\sim 1 \mathrm{ng}$ $\mathrm{cm}^{-2}$ or less) on the surface of $L$. obtusa. Moreover, surface concentrations of furanones on specific parts of the thallus, or from samples taken at different times of the year from this study, can exceed $1.5 \mu \mathrm{g} \mathrm{cm}^{-2}$. This is 3 orders of magnitude higher than levels of metabolites on the surface of $L$. obtusa.

Comparisons of the ultrastructure of Delisea pulchra and Laurencia obtusa are consistent with the difference in levels of surface metabolites between the 2 algae. Furanones in $D$. pulchra are contained in specialised vesicle cells which are present at the surface of the plant (Dworjanyn et al. unpubl.). Similar structures also occur in other genera in the chemically rich family Bonnemaisoniaceae (to which the genus Delisea belongs) (Womersley 1996), suggesting that other members of this family may also be able to use secondary metabolites to mediate surface interactions. In contrast, the terpenoid metabolites produced by Laurencia species are stored in membrane-bound vesicles'corps en cerise' - which occur within the outer cortex of the plant (Young et al. 1980). These vesicles, and thus the metabolites contained within, are not typically released to the surface of the plant and the external environment (Howard 1978, in Hay et al. 1987, and this paper) except following damage to the plant. These observations suggest that even in those instances where the levels of secondary metabolites on the surface of a marine organism are not known, the ultrastructure of the organism may be very informative for inferring (or not) a surface mediating role for the metabolites. 
Having quantified whole plant chemistry and surface chemistry of Delisea pulchra and Laurencia obtusa, we can compare ecological roles of secondary metabolites from the 2 plants. Herbivores consume both internal and exterior parts of the thallus, and therefore would be expected to come into contact with metabolites from both species. Consistent with this observation, metabolites or extracts from both species appear to play a role as deterrents of feeding by herbivores. D. pulchra is a very low preference food of the generalist herbivores Tripneustes gratilla (Echinodermata) and Turbo undulatus (Mollusca), and long-term growth rates of $T$. gratilla fed monospecific diets of $D$. pulchra are less than those of individuals which are starved (Steinberg \& van Altena 1992). Both crude extract and furanones from $D$. pulchra incorporated into artificial diets strongly deter feeding by $T$. gratilla and $T$. undulatus (de Nys et al. unpubl.). Similarly, the few studies done to date on the ecological role of secondary metabolites from $L$. obtusa indicate a feeding deterrent role for at least some of the metabolites against some herbivores (Hay et al. 1987, Paul et al. 1988). Palisadin A (although not aplysistatin and palisadin B) deterred feeding by the herbivorous fish Zebrasoma flavescens in laboratory assays and by mixed assemblages of herbivorous fishes in field assays (Paul et al. 1988), although it had no effect on feeding by the herbivorous fish Siganus doliatus (Hay et al. 1988). Other structurally similar metabolites from L. obtusa from other locations and from other species of Laurencia have strong deterrent effects against herbivores (e.g. elatoli Hay et al. 1987).

Furanones and metabolites from Laurencia spp. also deter the settlement and growth of ecologically relevant marine fouling organisms in both laboratory (de Nys et al. 1995, 1996. Steinberg et al. 1998) and, for furanones, field studies (Maximilien 1995. Hodson et al. 1997). While the levels of secondary metabolites present at the surface of Delisea pulchra are sufficient to deter ecologically relevant fouling organisms, for $L$. obtusa they are not. For example, in laboratory assays the most abundant metabolite on the surface of $D$. pulchra, compound 3 (Fig. 4 in de Nys et al. 1995), strongly deterred the settlement and growth of spores of the locally common epiphyte Ulva sp. at concentrations (25 $\mathrm{ng} \mathrm{cm}^{-2}$ ) less than those measured on the surface of the plant. In similar assays with metabolites from L. obtusa (Table 1 in Steinberg et al. 1998, de Nys et al. unpubl.), palisadin $A$ and $5 \beta$-hydroxyaplysistatin significantly deterred the settlement of the epiphytic green alga Ulva sp. and the bryozoan Bugula neretina at concentrations of 0.1 to $1 \mu \mathrm{g} \mathrm{cm}^{-2}$ respectively, while palisol deterred Ulva sp. at $1 \mu \mathrm{g} \mathrm{cm}^{-2}$ and $B$. neretina at $10 \mu \mathrm{g} \mathrm{cm}^{-2}$. However, these concentrations are 2 to 4 orders of magnitude greater than the concentration of these metabolites present on the surface of the plant. These studies highlight the importance of understanding the quantitative distribution of these compounds in order to determine their ecological role(s).

We believe the methods presented here provide a procedure by which non-polar crude extracts or pure metabolites from the surface of seaweeds (and potentially other organisms) can both be quantified and used to 'calibrate' realistic tests of the effects of metabolites on epibiota. This method may also be a useful tool in addressing the role of surface chemistry in other surface mediated interactions such as the chemical defence of marine larvae (Lindquist \& Hay 1996) and for comparing the effects of surface-bound versus water soluble chemical cues on the settlement of algal propagules and invertebrate larvae (e.g. Walters et al. 1996, Jennings \& Steinberg 1997).

Acknowledgements. We thank Tim Charlton for his invaluable chemistry expertise, and David Carson for assistance with field work. We acknowledge the contribution of the Biomedical Mass Spectrometry Unit and the Microscopy Facilities at UNSW. The research was supported by an ARC Postdoctoral Research Fellowship to R.d.N., an Australian Postgraduate Award to S.A.D., and an ARC Large Grant (A.19530672) to P.D.S.

\section{LITERATURE CITED}

Battista PJ (1995) Antifouling compounds from the red alga Laurencia obtusa. Honours thesis, University of Newcastle, Australia

Chapman RF, Bernays EA (1989) Insect behavior at the leaf surface and learning as aspects of host plant selection. Experientia 45:215-222

Clare AS (1996) Marine natural product antifoulants: status and potential. Biofouling 9:211-229

D'Antonio C (1985) Epiphytes on the rocky intertidal red alga Rhodomela larix (Turner) C. Agardh: negative effects on the host and food for herbivores? J Exp Mar Biol Ecol 86: $197-218$

Davis AR, Targett NM, McConnell OJ, Young CM (1989) Epibiosis of marine algae and benthic invertebrates: natural products chemistry and other mechanisms inhibiting settlement and overgrowth. Bioorg Mar Chem 3:86-114

de Nys R, Coll JC, Bowden BF (1992) Delisea pulchra (cf. fimbriata) revisited. The structural determination of two new metabolites from the red alga Delisea pulchra. Aust J Chem 45:1625-1632

de Nys R, Coll JC, Price IR (1991) Chemically mediated interactions between the red alga Plocamium hamatum and the soft coral Sinularia cruciata. Mar Biol 108:315-320

de Nys R, Steinberg PD, Rogers CR, Charlton TS, Duncan MW (1996) Quantitative variation of secondary metabolites in the sea hare Aplysia parvula and its host plant, Delisea pulchra. Mar Ecol Prog Ser 130:135-146

de Nys R, Steinberg PD, Willemsen P, Dworjanyn SA, Gabelish CL, King RJ (1995) Broad spectrum effects of secondary metabolites from the red alga Delisea pulchra in antifouling assays. Biofouling 8:259-271

de Nys R, Wright AD, Konig GM, Sticher O (1993) New halogenated furanones from the marine alga Delisea pulchra 
(cf. fimbriata). Tetrahedron 49:11213-11220

Dixon JS, Schroeter SC, Kastandiek J (1981) Effects of the encrusting bryozoan, Membranipora membranacea, on the loss of blades and fronds of the giant kelp Macrocystis pyrifera. J Phycol 7:341-345

Eigenbrode SD, Espelie KE, Shelton AM (1991) Behavior of neonate diamondback moth larvae [Plutella xylostella (L.)] on leaves and on extracted leaf waxes of resistant and susceptible cabbages. J Chem Ecol 17:1691-1704

Erickson KL (1983) Constituents of Laurencia. In: Scheuer PJ (ed) Marine natural products, chemical and biological perspectives. V. Academic Press Inc, New York, p 131-257

Farrant PA, King RJ (1989) The Dictyotales (Algae: Phaeophyta) of New South Wales. Proc Linn Soc NSW 110:369-405

Hay ME (1996) Marine chemical ecology: what's known and what's next? J Exp Mar Biol Ecol 200:103-134

Hay ME, Duffy JE, Fenical W (1988) Seaweed chemical defenses: among-compound and among-herbivore variance. Proc 6th Int Symp Coral Reef 3:43-48

Hay ME, Fenical W (1988) Marine plant-herbivore interactions: the ecology of chemical defence. Annu Rev Ecol Syst 19:111-145

Hay ME, Fenical W, Gustafson K (1987) Chemical defence against diverse coral-reef herbivores. Ecology 68: $1581-1591$

Hodson SL, Burke CM, de Nys R, Steinberg PD, Christie G, Christov V, Rothlisberg PC (1997) Mariculture antifouling: polymer carriers for natural and commercial compounds. Proc US-Pacific Rim Workshop on Emerging Nonmetallic Materials for the Marine Environment, US Office of Naval Research, Washington, DC, p 353-364

Holmström C, Kjelleberg S (1994) The effect of external biological factors on settlement of marine invertebrate larvae and new antifouling technology. Biofouling 8:147-160

Jennings JG, Steinberg PD (1997) Phlorotannins versus other factors affecting epiphyte abundance on the kelp Ecklonia radiata. Oecologia 109:461-473

Kazlauskas R, Murphy PT, Quinn RJ, Wells RJ (1977) A new class of halogenated lactones from the red alga Delisea fimbriata (Bonnemaisoneaceae). Tetrahedron Lett 1:37-40

Kushmaro A, Loya Y, Fine M, Rosenberg E (1996) Bacterial infection and coral bleaching. Nature 380:396

Lindquist N, Hay ME (1996) Palatability and chemical defence of marine invertebrate larvae. Ecol Monogr 66: $431-450$

Littler MM, Littler DS (1995) Impact of CLOD pathogen on Pacific coral reefs. Sclence 267:1356-1360

Maximilien R (1995) Inhibition of marine bacteria by seaweed secondary metabolites. Honours thesis, University of New South Wales, Sydney

O'Brien TP, McCully ME (1981) The study of plant structure: principles and selected methods. Termarcarphi, Melbourne

Paul VJ, Wylie CR, Sanger HR (1988) Effects of algal chemical defenses toward different coral-reef herbivorous fishes: a preliminary study. Proc 6th Int Symp Coral Reef 3:73-78

Pawlik JR (1992) Chemical ecology of the settlement of benthic marine invertebrates. Oceanogr Mar Biol Annu Rev 30: $273-335$

Sand-Jensen K (1977) Effects of epiphytes on eelgrass photo- synthesis. Aquat Bot 355-63

Schmitt TM, Hay ME, Lindquist N (1995) Constraints on chemically mediated coevolution: multiple functions for seaweed secondary metabolites. Ecology 76:107-123

Sieburth JM, Conover JT (1965) Sargassum tannin, an ant1biotic which retards fouling. Nature 208:52-53

Sokal RR, Rohlf FJ (1995) Biometry, 3rd edn. WH Freeman \& Co, New York

Steinberg PD de Nys R, Kjelleberg S (1998) Chemical inhibition of epibiota by Australian seaweeds. Biofouling 12 $227-244$

Steinberg PD, van Altena I (1992) Tolerance of marine invertebrate herbivores to brown algal phlorotannins in temperate Australasia. Ecol Monogr 62:189-222

Stevens JF, Hart HT, Wollenweber E (1995) The systematics and evolutionary significance of exudate flavanoids in Aeonium. Phytochemistry 39:805-813

Tamburri MN, Zimmer-Faust RK (1996) Suspension feeding basic mechanisms controlling recognition and ingestion of larvae. Limnol Oceanogr 41(6):1188-1197

Tulloch AP (1987) Epicuticular waxes of Abies balsamea and Picea glauca: occurrence of long-chain methyl esters Phytochemistry 26:1041-1043

Wahl M (1989) Marine epibiosis. 1. Fouling and antifouling some basic aspects. Mar Ecol Prog Ser 58:175-189

Wahl M, Hay ME (1995) Associational resistance and shared doom: effects of epibiosis on herbivory. Oecologia 102 $329-340$

Walters LJ, Hadfield MG, Smith CM (1996) Waterborne chemical compounds in tropical macroalgae: positive and negative cues for larval settlement. Mar Biol 126:383-393

Williams GA, Seed R (1992) Interactions between macrofaunal epiphytes and their host algae. In: John DM, Hawkins SJ, Price JH (eds) Plant-animal interactions in the marine benthos. Clarendon Press, Oxford, p 189-211

Wollenweber E, Valant-Vetschera KM, Ivancheva S, Kuzmanov B (1987) Flavonoid aglycones from the leaf surface of some Achillea species. Phytochemistry 26:181-182

Womersley HBS (1984) The marine benthic flora of southern Australia. Part I. South Australia Government Printing Division, Adelaide

Womersley HBS (1987) The marine benthic flora of southern Australia. Part II. South Australia Government Printing Division, Adelaide

Womersley HBS (1996) The marine benthic flora of southern Australia. Part IIIb. Australian Biological Resources Study, Canberra

Young DN, Howard BM, Fenical W (1980) Subcellular localization of brominated secondary metabolites in the red alga Laurencia snyderae. J Phycol 16:182-185

Zobel AB, Brown SA (1988) Termination of furanocoumarins on the leaf surface of Ruta graveolens with an improved extraction technique. J Nat Prod 51:941-946

Zobel AB, Brown SA (1990a) Dermititis-inducing furanocumarins on the leaf surfaces of eight species of rutaceous and umbelliferous plants. J Chem Ecol 16:693-700

Zobel AB, Brown SA (1990b) Seasonal changes of furanocoumarin concentrations in leaves of Heracleum lanatum. J Chem Ecol 16:1623-1633

Submitted: August 25, 1997; Accepted: November 7, 1997 Proofs received from author(s): January 19, 1998 